\title{
Forms of Freedoms: Marie Darrieussecq, Catherine Malabou, and the Plasticity of Science
}

\section{Benjamin Dalton}

Number 115, Winter 2020

Précisions sur les sciences dans l'oeuvre de Marie Darrieussecq

URI: https://id.erudit.org/iderudit/1067884ar

DOI: https://doi.org/10.7202/1067884ar

See table of contents

Publisher(s)

Department of French, Dalhousie University

ISSN

0711-8813 (print)

2562-8704 (digital)

Explore this journal

Cite this article

Dalton, B. (2020). Forms of Freedoms: Marie Darrieussecq, Catherine Malabou, and the Plasticity of Science. Dalhousie French Studies, (115), 55-73.

https://doi.org/10.7202/1067884ar

\section{Article abstract}

This article brings the writing of Marie Darrieussecq into dialogue with the philosophy of Catherine Malabou, exploring how both think the mutability and transformability of the body in relation to recent scientific and technological discovery and innovation. From the metamorphosis of a woman into a sow in Truismes (1996) to the cloning of human life in Notre vie dans les forêts (2017), Darrieussecq's novels foreground the body as a site of constant change and reinvention. Meanwhile, Malabou's interdisciplinary elaboration of the concept of 'plasticity' between continental thought and the biological sciences reveals all structures and forms of life to be plastic and intrinsically open to change, from the neuroplasticity of the human brain to the epigenetic development of organisms. This article presents both Darrieussecq and Malabou as writers and thinkers of plasticity, exploring how their respective plasticities develop through a relationship to science which is itself changeable and ambiguous. In different but converging ways, both suggest how science discovers and innovates with the plasticity of life, whilst often also controlling and manipulating this same plasticity in the context of late capitalism. More optimistically, this article proposes that Darrieussecq and Malabou also envisage a becoming plastic of the sciences themselves, liberating plasticity as a discourse of freedom as a thinking with science, literature, and philosophy.
This document is protected by copyright law. Use of the services of Érudit (including reproduction) is subject to its terms and conditions, which can be viewed online.

https://apropos.erudit.org/en/users/policy-on-use/ 


\title{
Forms of Freedoms: Marie Darrieussecq, Catherine Malabou, and the Plasticity of Science ${ }^{1}$
}

\author{
Benjamin Dalton
}

7

rom the account of a woman's metamorphosis into a pig in her first novel Truismes (1996) to the genetic (re)production of clones in her most recent Notre vie dans les forêts (2017), the novels of Marie Darrieussecq foreground the transformability and plasticity of the body. This interest in corporeal mutability is inextricably bound with Darrieussecq's literary engagement with ongoing scientific discourses, which map the complexity of organic life across neuroscience, biology, psychology, as well as the increasingly intimate relationship between organic life and technology in informatics, robotics, bio-technology, bio-engineering, medical technology, and many other domains ${ }^{2}$. This article explores Darrieussecq's imagining of the mutable body through and beyond science and technology in relation to the work of the contemporary French philosopher Catherine Malabou on the concept of "plasticity". Thinking at the intersections of philosophy, psychoanalysis, neuroscience, and epigenetics, among other disciplines, Malabou elaborates her concept of plasticity as a capacity for mutation and transformation intrinsic to all forms of life, from the mutability of the neuroplastic human brain to the dynamics of epigenetics in the development of organisms. Darrieussecq and Malabou, then, both imagine how our thinking of transformation and metamorphosis must change in light of ongoing scientific and technological discoveries. Conceptualising this changing transformation through literature and philosophy respectively, Darrieussecq and Malabou intersect as writers and thinkers of plasticity.

The plasticities of Darrieussecq and Malabou, however, develop via an engagement with science and technology which is itself highly ambivalent and changeable. On one hand, science and technology provide tools through which the plasticity and mutability of organic life is discovered and conceptualized; for example, in different ways, Darrieussecq and Malabou both look to the neuroscientific elaboration of the plasticity of the brain to inspire their own thinking of the mutability of identity. On the other hand, however, Darrieussecq and Malabou explore how science and technology in late capitalism can become ideologically corrupt mechanisms which harness, colonise and even occlude the very plasticity that they discover, for example in the case of medical technologies which police and sculpt the body's form in accordance with normative structures ${ }^{3}$. My argument is that, out of this ambivalent relationship, Darrieussecq and Malabou fight to liberate plasticity as a discourse of freedom, both from and for science. While both Darrieussecq and Malabou are inspired by scientific and technological articulations of plasticity, they also think plasticity as a force which has the power to exceed, interrupt and critique

1 I dedicate this article to my mother, Rosie Dalton (1964-2019), whose wonder and fearlessness in the face of her own metamorphosis, and whose belief in the power of the body in transformation, will inspire me in everything I ever write.

2 For an overview of Darrieussecq's interest in contemporary neurobiological understandings of the brain as the material site of psychic life, see Kemp's Writing the Mind (149-77); see also Damlé's "Posthuman Encounters" for a discussion of questions of gender in relation to technology in Darrieussecq.

3 Indeed, beyond Darrieussecq and Malabou, theories of gender and sexuality have noted how medical and technological discourses have the power to construct and maintain the parameters of the normative body and technology to construct and maintain the parameters of the normative body, such as in Foucault's The History of Sexuality 1. The Will to Knowledge; in Butler's Gender Trouble: Feminism and the Subversion of Identity and Bodies that Matter: On the Discursive Limits of "Sex"; and in Preciado's Testo Junkie: Sex, Drugs, and Biopolitics in the Pharmacopornographic Era. 
ideological capture by these same discourses, and even transform and plasticise these discourses in return ${ }^{4}$.

This article explores Truismes and Notre vie dans les forêts, tracing between them the development of a thinking of plasticity in Darrieussecq's work as mode of metamorphic freedom. Both novels are set in advanced capitalist, totalitarian futures in which scientific and technological advancements are presented as malevolent forces which control and exploit the general population. In Truismes, the protagonist narrator is a young woman who, suddenly and for no apparent reason, discovers she is turning into a sow; the medical sciences ultimately fail to explain or reverse this transformation, and the narrator finds herself exiled from society and forced to create a new life for herself in the wild. Notre vie, meanwhile, imagines a universe in which the rich pay for clones of themselves which they can use for transplantable body parts if they are ill or injured. Here, the protagonist narrator is part of a resistance group which plots to free all the clones from the "Centres de repos", in which the clones are kept anaesthetized, and start a new life of freedom in the forest, training and sculpting the clones into an army of resistance. I argue that the transformation into a pig in Truismes and the sculpting of the clones in Notre vie constitute explorations of the formation and transformation of plastic life forms as critical of and resistant to the scientific and technological discourses which try to control, exploit, or occlude their plasticity. Then, turning in particular to Notre vie, I demonstrate how these plasticities in turn transform and emancipate science from a logic of totalitarian control.

Darrieussecq's exploration of the plasticity of life as a locus of transformation and resistance resonates with Malabou's philosophical definition of plasticity. Malabou describes plasticity as the tripartite capacity to give, receive, and explode form. Her plasticity is a compound of "constructive" plasticity, such as that found in the plastic arts, and the "destructive" plasticity of plastiquage:

L'adjectif 'plastique' toutefois, s'il s'oppose à 'rigide', 'fixe', 'ossifié', ne signifie pas pour autant 'polymorphe'. Est plastique ce qui garde la forme, comme le marbre de la statue qui, une fois configuré, ne peut retrouver sa forme initiale. 'Plastique' désigne donc ce qui cède à la forme tout en résistant à la déformation. [...] La plasticité même du terme de plasticité le conduit aux extrêmes, à une figure sensible qui est la prise de forme (la sculpture) et à l'anéantissement de toute forme (l'explosif). (L'Avenir de Hegel 21)

Plasticity, then, describes both transformation and resistance to transformation. Further, Malabou's interdisciplinary contextualisations of plasticity across philosophy, art, neuroscience, etc., show plasticity to be as multiple as it is hybrid, always evading capture or control by any one discourse, scientific or otherwise. Christopher Watkin underlines Malabou's own insistence that the concept of plasticity itself is plastic and constantly mutating (85), whilst Gregor Moder argues Malabou's plasticity should not be considered singular but indeed as a "pack" of "plasticities" in the plural (828). These tensions between transformability and resistance, formation and explosion, singularity and plurality, establish plasticity as a potentiality for freedom; its transformations resist any totalising appropriation, instrumentalisation, or ossification of their forms. Liberated as plastic, all form is open to radical change and difference.

4 Given the diverse range of scientific and technological discourses with which both Darrieussecq and Malabou engage, and the ambivalent relationship between these discourses expressed in their work, I use the terms "science", "technology", and "technoscience" as irreducibly slippery signifiers to describe the complex web of intersecting forces which seek to document, manipulate, or extend the plasticity of organic life. This slipperiness echoes Andrew Pickering's notion of the "mangle of practice" in which plural and diverse scientific and social productions undergo "unpredictable transformations" when mangled together (23) and Donna Haraway's definition of technoscience as "a generative matrix" and "heterogeneous cultural practice" (50). 
Whilst Darrieussecq has been explored in relation to other philosophies of transformation ${ }^{5}$, connections between her work and Malabou's thought remain unexplored. Meanwhile, despite the abundance of literary references in her philosophy, and her emphasis on the importance of future encounters between literature and science, there are relatively few studies which engage Malabou's thought with literary and filmic texts ${ }^{6}$. I do not read Darrieussecq as an "illustration" of Malabou's plasticity, but rather propose an encounter in which Darrieussecq and Malabou emerge as writers and thinkers of plasticities in their own rights. This encounter promises symbiotic transformations of literature, philosophy, and science into plastic forms of freedoms.

\section{Anti-plastic Science and the Flexibility of Control}

In Truismes and Notre vie, the plasticity of the transformable body and brain is contrasted with ideologically corrupt, anti-plastic sciences which seek to control populations precisely by colonising and denying their plasticity. These anti-plastic sciences are intrinsic to the operation of the totalitarian systems of control described in both novels. In Truismes, the sciences appear as a host of malevolent and coercive medical discourses and political apparatuses which seek to contain, control and exile the unruly plasticity of the narrator's transforming body. Set in an uncanny, dystopian future, the backdrop of Truismes imagines a totalitarian Paris in which politicians campaign for "un monde plus sain" to put a stop to "une période de mutation très sale" (66; emphasis in the original), politicising a biotechnological hygienics in which bodily transformations are rendered abject and marginal bodies are policed and corrected. Thomas Phillips maps the capitalist flows of violence at work in the novel (93), whilst Andrew Asibong depicts the biopolitical mechanisms of the society which convert liminal bodies into "bare life" and oversee "the violent eradication of all bodily 'deviance', sexual, racial or otherwise" (171). This biopolitical capture also characterises the treatment of the clones in Notre vie which are rendered non-human and disposable, artificially maintained in a vegetative state for later use, the body's organic propensity to plastic growth and development entirely occluded. These mechanisms of control, I argue, occlude plasticity in order to render bodies more docile; there can be no freedom without plasticity's promise of transformation and resistance.

Whilst Malabou stresses throughout her work that philosophy can no longer afford to ignore the findings of science, and that science can and should constitute a space of philosophical and sociopolitical inspiration and invention, she also shows how science can only too easily fall prey to ideologies of control, reproducing political and economic violences rather than inventing solutions to these violences ${ }^{7}$. Across her critique of scientific and technological discourses of plasticity from Que faire de notre cerveau? (originally published in 2004) to "Repetition, Revenge, Plasticity" (2018), Malabou shows how certain scientific and technological domains imitate capitalist logics, whether consciously or unconsciously, precisely by confusing plasticity for flexibility or adaptability. In Que faire, Malabou shows how neuroscientific discourses describe the

5 See, for example, Damlé's reading of Darrieussecq's transformations alongside Deleuzian philosophy in The Becoming of the Body (123-53).

6 See Malabou's "What is Neuro-literature?" (2016) and Williams' suggestion for further study of the literary dimension of Malabou's philosophy in "Plasticity, in Retrospect: Changing the Future of the Humanities" (19); for examples of existingwork which analyses literary and filmic texts in relation to Malabou's plasticity, see: Gabriela García Hubard, "Quelques réflexions: de la plasticité aux discours postcoloniaux"; S. Pearl Brilmyer, "Plasticity, Form, and the Matter of Character in Middlemarch"; and Ben Tyrer, "Trauma Without a Subject: On Malabou, Psychoanalysis and Amour".

7 See, for example, Malabou's underlining the importance of future collaboration between philosophy and science in "The Future of the Humanities" (2010) and "Pour la rencontre entre philosophie et neuro-sciences" (2014). In the latter, Malabou articulates how we must balance a critical alertness to scientific ideology with the fact that "l'aventure des neurosciences contemporaines est une des choses les plus exaltantes qui soient aujourd'hui" (n. pag.). 
brain's plasticity in purely positive terms, imagining the brain as capable of modulating and adapting its synaptic form over the course of a lifetime in response to experience and injury; in other words, for neuroscience, the brain's plasticity is purely constructive and never destructive ${ }^{8}$. This, she critiques, risks reducing the neuroplasticity of the brain to the one-sided, passive attributes of flexibility or adaptability which mirror neo-liberal, neomanagement ideals of the perfectly docile workforce, able to adapt and repeat endlessly, without being able to resist or create. Malabou states: "aujourd'hui, la plasticité est occultée en son sens véritable, on tend en effet à lui substituer constamment son faux ami, la flexibilité. [...] Pourtant, la flexibilité est l'avatar idéologique de la plasticité" (55-6; emphasis in the original). An ideologically co-opted science has modelled the plastic brain in the image of the capitalist production. Further:

Être flexible, c'est recevoir la forme ou l'empreinte, pouvoir se plier, prendre le pli, non le donner. Être docile, non exploser. Il manque en effet à la flexibilité la ressource de la donation de forme, le pouvoir de créer, d'inventer ou même d'effacer une empreinte, le pouvoir de styler. La flexibilité est la plasticité moins son génie. (Que faire 57-8; emphasis in the original)

Whilst plasticity can create and invent new forms, flexibility, like elasticity or adaptability, can only reproduce the same forms over and over, passively yielding to forms imposed upon it rather than claiming or inventing its own forms ${ }^{9}$.

This tension between docile capitalist elasticity and creative plasticity is played out, I argue, in Truismes' narrator's exploitation and subsequent rejection by the workforce; when she goes for a job in a perfumery at the beginning of the novel, a job which later includes unregulated sex work in a back room, she is expected to bend and stretch elastically to any demand, withstanding any degree of exploitation. Strikingly, when she goes for an interview at the perfume boutique, it is the elasticity of her skin which seals the deal:

Le directeur de la chaîne m'avait prise sur ses genoux et me tripotait le sein droit, et le trouvait visiblement d'une élasticité merveilleuse. [...] Le directeur de la chaîne tenait mon sein droit dans une main, le contrat dans l'autre main. Je sentais mon sein qui palpitait, c'était l'émotion de voir ce contrat si près d'être signé, mais c'était aussi cet aspect, comment dire, pneumatique de ma chair. (11; emphasis in the original)

That the boss literally has the narrator's elastic breast in one hand and the contract in the other further establishes the connection between the narrator's capture by the capitalist workforce and elasticity as a material characteristic. The use of the verb "palpitait" and the adjective "pneumatique" to describe the narrator's flesh further describes the mechanics of elasticity; the narrator's emotional register is reduced to a series of machinic repetitions by the approaching contract, with the reference to pneumatics connoting a slick, repeated action of inflation and deflation, elastically stretching a form before returning it to its original state, reproducing and submitting to form rather than creating new form. The narrator recognises that the elasticity of her skin might figure among the "tout premiers symptômes" (11) of her metamorphosis; at this early stage, her transformation is elastic

8 Malabou goes on to explore the destructive side of (neuro)plasticity in more depth in Les Nouveaux blessés: de Freud à la neurologie, penser les traumatismes contemporains (2007) and Ontologie de l'accident: Essai sur la plasticité destructrice (2009). Malabou seeks to deconstruct the fact that "[e]n science, en médecine, en art, dans le domaine de l'éducation, l'usage que l'on fait du terme 'plasticité' est toujours positif' (Ontologie de l'accident 10).

9 Throughout her work, Malabou describes plasticity in opposition to other formal and material characteristics such as flexibility, polymorphism, elasticity, etc. While we might arguably differentiate between these individual terms, they are united in their non-plastic status because of their common passivity, as Watkin notes of elasticity and flexibility (98). 
and therefore acceptable as a pliable and exploitable materiality, displaying the suppleness of "la plasticité moins son génie" (Que faire 57; emphasis in original).

The corporate demand for corporeal elasticity does not stop at skin level, but also colonises the narrator's psychic mechanisms: "Le directeur de la parfumerie m'avait fait mettre à genoux devant lui et pendant que je m'acquittais de ma besogne je songeais à ces produits de beauté, à comme j'allais sentir bon, à comme j'aurais le teint reposé" (12). Whilst the narrator's "besogne" suggests oral sex as yet another machinic, repetitive task, her internal thought process becomes equally mimetic, reproducing visions of the beauty products of her new consumerist environment as a looped advertising reel. Indeed, Colette Trout talks of the narrator's "discours de perroquet" at the beginning of the novel (15), Jeannette Gaudet describes the "Candide-like naïveté" with which the narrator reproduces the misogynist structures of her surroundings (182), and Darrieussecq herself speaks of her narrator's reproducing "les clichés, les on-dit des journaux, tout ce qu'elle entend autour d'elle" (Darrieussecq and Gaudet 109). Rather than being the author of her own psychic processes, the sculptor of her own plastic mind, the narrator's subjugation by the workforce forces her to elastically reproduce the capitalist flows of the world around her, her thoughts generating and generated by the proscribed forms and objects that she both has to be and to sell. Disallowed a materiality of her own, the narrator is forced to act as a passive vessel or receptacle that other forms inhabit and pass through.

This professional elasticity extends to her private life. Having sex with her boyfriend in the changing rooms of a boutique, the narrator says: "Je me voyais dans la glace, je voyais les mains d'Honoré sur mes reins, ses doigts creusaient des sillons élastiques au creux de ma peau" (15). The narrator sees herself reproduced in the mirror as passive, elastic form, shaped and given form by the appropriating touch of Honoré, the setting of the underwear store adding further to the capitalist logics of reproductive consumerism and objectification. Malabou specifies that form is vital for identity and resistance, and that elasticity, alongside its avatars of polymorphism or flexibility, is incapable of determining its own form:

On ne se forme qu'à partir d'une résistance à la forme elle-même; le polymorphisme, ouvert à toutes les formes, capable de revêtir tous les masques, toutes les postures, toutes les attitudes, n'engendre que la défaite de l'identité. La flexibilité, qui ne donne à éprouver aucune tension véritable entre maintien et évolution mais les confond au sein d'une pure et simple logique d'imitation et de performance, n'est pas créatrice. Elle est purement reproductrice et normative. (Que faire 166-67)

Elasticity, flexibility and polymorphism reproduce rather than create. Paul B. Preciado explores how advanced capitalism fashions and regulates the docile, consumer body through bio-technological and medical means by which "[t]he pharmacopornographic business is the invention of a subject and then its global reproduction" (36; emphasis in the original). This pharmacopornographic system of control echoes Malabou's critique of scientific ideology which naturalises the reproduction of the subject as elastic and flexible rather than invents tools for the discovery or extension of the subject's plasticity: "la flexibilité se surimpose à la plasticité, et ce y compris au sein des discours scientifiques qui croient la décrire en toute 'objectivité'" (Que faire 57). Indeed, the narrator's perfumery is a treasure-trove of pharmacopornographic, bio-engineered remedies for maintaining the reproductive elasticity of the body such as the "ensemble de crèmes Gilda à l' $A D N$ suractivé pour renouvellement cellulaire et recombinaisons des macromolécules" (32; emphasis in the original) and the "gel micro-cellulaire spécial épiderme sensible contre les capitons disgracieux" (47; emphasis in the original), both creams which inject the discoveries of current regenerative biology and medicine into beauty-care as a means of misogynistic regulation of the gendered body; whilst science discovers and comprehends 
the body's plastic potentialities, it engineers this discovery for elastic maintenance rather than plastic invention. Most horrifically, when the narrator confides in her boss that her clients are beginning to "dépasser les bornes" with her sexually, he simply gives her a "crème spéciale" in order to "attendrir les parties sensibles et assouplir le tout" (36-7), as if in an attempt to smooth over any exploitation or abuse as efficiently as possible, prepare the narrator's body to withstand more of the same, and get her quickly back to work. Further, this obsession with the bio-chemical maintenance of the eternally young, reproductive, sexually flexible body echoes across the social make-up of the novel with the government's encouragement to increase a sluggish birthrate (66) and the narrator's lamentation that her boyfriend Honoré needs "une vraie femme" who can "faire un enfant et tout ça" (74). Fearing loss of employment, the narrator has no choice but to comply with this enforced reproductive flexibility; in Malabou's formulation, we inhabit a world in which "qui n'est pas flexible mérite de disparaître" (121). Any failure to function, physically or psychically, is pathologised as a "[maladie] de la flexibilité" (121; emphasis in the original).

This use of science to regulate the body biochemically as a docile site of reproduction and servitude echoes the maintenance of the clones in Notre vie. Whilst the clones, as repetitions of the organic human body, have the capacity for plasticity - plastic brains that can learn, bodies that can develop and transform - the manufacturers of the clones repress this plastic potentiality, ridding them of any agency or humanity. The clones are designed to reproduce the same, maintaining the bodies of their "souche" and rendering them immortal. The clones, stored in the "Centres de repos", are "techniqués de tous côtés" (68), fed via intravenous tubes, and anesthetised to occlude pain and consciousness. Like at the beginning of Truismes, we again see the paradigm of elasticity or flexibility: Truismes' initially elastic, unconscious narrator is maintained like a clone, disallowed thought or sensation and used for spare parts. Just like the creams and medical interventions designed to return the narrator back to an acceptable elasticity in Truismes, the clones in Notre vie are a prophylactic, hygienic measure; manufactured as organic life-insurance, they occlude the possibility of any event, of any exposure to freedom, and instead maintain the law of infinite reproduction and survival. Indeed, echoing the ecological toxicity of Truismes in which politicians campaign for "un monde plus sain" (66; emphasis in the original), the clones are there to cancel out the risk of damage from the toxic environment of "la pollution de l'air, le charbon $[\ldots]$ les produits chimiques [...]. On tombait malade. On n'y pouvait rien. Les moitiés étaient là pour ça" (96). Describing her own clone, the narrator shows how she has been brainwashed to think of the clones as detached reproductions rather than creations capable of their own life: "Marie = réservoir de pieces détachées. Moitié = sécurité. Enfin c'est toute la grande histoire qu'on nous a racontée" (52). The clones, like the narrator at the beginning of Truismes, are maintained as unconscious receptacles, denied the plastic potentiality of creation. Marie is told of her clone that "son cerveau était vide. 102008-Bidule-Chose est une non-personne [...]. Un lot d'organes. Une mise à disposition et une assurance-vie" (85-6). Further, the clones are "des réceptacles d'organes [...] un puzzle d'organes dissociables, en sursis" (97-8).

The clones' being "en sursis", in suspension, describes the atemporality of the elastic, reproduced body in which this body is severed from history, denied any encounter with the Event ${ }^{10}$, forced to repeat the same form forever, and therefore denied its plasticity. Just as the bio-technological innovation of clones in Notre vie is put to use for the repetition of the same rather than the creation of the new, Malabou laments the bathos of the failure to respond politically to the neuroscientific discovery of plasticity, in which the potentially

10 Here, I am not refering to the specific conceptualisation of the 'Event' in the work of any one thinker, but evoking the more generalised philosophical designation of a radical rupture, a change, or of the happening of something new or unforeseen. 
radical knowledge of the brain's mutability has not been translated into political consciousness or revolution, but rather has been swallowed by capitalist structures:

Force est de constater le décalage énorme qui existe entre toutes les promesses d'avenir, les désirs d'une autre histoire, d'une autre vie suscités par la toute nouvelle vision du cerveau, par ce continent qu'est aujourd'hui la plasticité cérébrale, et le peu d'espace politique, philosophique ou culturel dans lequel ces promesses peuvent se déployer théoriquement et du même coup se réaliser. Encore une fois, il semble que la révolution neuronale n'ait rien révolutionné pour nous s'il est vrai que notre cerveau ne nous sert qu'à mieux nous déplacer, à mieux travailler, à mieux sentir ou à mieux obéir. (Que faire 159)

Just as innovations in genetic engineering are used to secure the lives of the rich few in Notre vie, the potentially revolutionary (neuro)plasticity discovered by the neurosciences is put to work in the name of economic security rather than change or difference. Malabou quotes from Alain Ehrenberg's La Fatigue d'être soi (1998): "L'individu aujourd'hui [...] n'est ni malade ni guéri. Il est inscrit dans de multiples programmes de maintenance" (Que faire 159-60). The universe of Notre vie is also populated by robots which carry out banal tasks and are programmed via associations such as "bleu = ciel = vague à l'âme" (18); here, each "=" founds a grammar of equivalence and sameness, and again a logic of elasticity. These robots "ne dorment jamais, ils cliquent désormais et savent reproduire, à l'infini, les associations les plus basiques" (29-30), an eternal return which underlines "le temps infini qu'ont les machines" and "leurs infinies capacités de recoupement" (34).

In "Repetition, Revenge, Plasticity", Malabou extends her thinking of flexibility in Que faire to reflect on more recent technoscientific innovations, demonstrating how contemporary molecular biology, specifically genetics and epigenetics, and research into artificial intelligence, are also driven by logics of reproduction and repetition. Stem-cell research presents us with new possibilities for regenerative medicine in which "to duplicate, to repeat oneself" has led to "[p]lastic self-replacement" becoming "the new paradigm", whilst artificial intelligence demonstrates an attempt to "simulate, double, and duplicate" the working of the brain through medical informatics, neuromorphic computing, neurorobotics and other domains (n. pag.). Malabou asks: "is the plasticity that can currently be found everywhere - in aesthetics, medicine, ecology, physics, psychology, neurobiology - actually what it proclaims to be, or does it merely coincide with flexibility, that sham of plasticity?" (n. pag.). Molecular biology and artificial intelligence risk denying the plasticity of organic life precisely in reducing it to a logic of repetition, a logic which "seeks revenge" against time, aging, and finitude. Malabou wonders: "is the post-humanist claim that human beings will become amortal not precisely a sign of such a revengeful tendency?" (n. pag.).

It is ironic, then, that the world of Notre vie repeats that "[s]'adapter = progrès = améliorer $[. .]=$. liberté" (61). Again, we hear the trap that Malabou debunks in Que faire whereby adaptability or flexibility is a false freedom, instead revealing itself to be the avatar of a repetitive "employability", and technological "innovation" is geared towards the preservation of the status quo: "Beneath all of the technological novelties of our time, I am not sure "we" actually want novelty" ("Repetition, Revenge, Plasticity" n. pag.). To truly embrace plasticity, on the other hand, would require us to forget our revenge against time, and to learn "to repeat differently" (n. pag.), to welcome the new, to add the "genie" of plasticity (Que faire 57) back into flexibility. Repetition does not have to equal sameness, or elasticity, but might itself become plastic, repeating precisely difference and transformation. Indeed, when the narrator of Notre vie recalls the very first clone - Dolly the sheep - she attributes Dolly's premature death not to the mechanism of cloning itself, but to the banal fact that she was kept indoors to prevent anything happening to her, dying 
from lack of exercise and poor air (123). Whilst the clone Dolly may have been able to "repeat differently" ("Repetition, Revenge, Plasticity" n.pag), in Darrieussecq's rendering, science ironically kills her precisely in attempting to preserve her from plastic change. Darrieussecq's Dolly, chained to flexible immortality, dies from being starved of contingency.

As we will now see, the metamorphosis into a sow in Truismes and the emancipation of the clones in Notre vie imagine moments of plasticity and plastic transformation as modes of resistance and freedom, even if often painful and violent, within universes governed by elastic, anti-plastic sciences. Documenting unruly transformations that refuse to comply, Truismes and Notre vie explore the possibility of freeing plasticity from the control of totalitarian science.

\section{The Coming of Plasticity: Escaping Science}

In Truismes, the docile efficiency of the narrator's body begins to fade as her transformation becomes more radical: "Or mon seul atout, c'était mon côté pneumatique, et là il faut bien avouer que je le perdais peu à peu. Encore un mois ou deux, et je ne pourrais plus du tout entrer dans ma blouse" (29; emphasis in the original). The narrator is no longer able to signify comfortably within the obedient sexual parameters demanded of her, and she articulates sexual desires and appetites "dont [elle] prenai[t] [elle]-même l'initiative" (40) earning her the wrath of her boss and threatening her employment. Further, any attempts to "correct" her transformation, be that via medical or behavioural intervention, fail. Her subjection to a "séance de remise en selle" (40) with her boss leaves her indifferent, and medical treatments prove ineffective; a beauty magazine warns the narrator that if she does not achieve "harmonie avec soi-même" she risks a cancerous "développement anarchique des cellules" (47; emphasis in the original), she is encouraged to visit plastic surgeons (48), and goes to see a dermatologist who injects her with a serum which only makes her nauseous (59). The narrator's loss of elasticity signals the coming of plasticity as a rebellious, non-compliant materiality which refuses science's injunction to repeat and reproduce as a docile, obedient subject.

Another shift away from the paradigm of reproductive elasticity to one of plasticity occurs when the narrator is told she is pregnant and undergoes an abortion. Whilst, as we have seen, the world of Truismes encourages copious reproduction, both of children and of obedient housewives charged with their care, this is no normal pregnancy ${ }^{11}$. The narrator complains: "mon ventre ne ressemblait pas du tout à celui d'une femme enceinte, ce n'était pas un beau globe rond mais des bourrelets que j'avais" (29). Rather than being the passive woman-receptical that the pharmacopornographic biopolitical regime promotes for the heightened birth rates of "un monde plus sain", like the passive clone-receptacles that incubate hygienic organs in Notre vie, the transformation of the narrator's whole body and not just her belly threatens to create new forms plastically rather than reproduce normative ones.

This pregnant plasticity is not tolerated at the abortion clinic, which is presented as a space of biomedical surveillance and punishment. A pro-life protester is chained to the operating table, condemning the narrator throughout the procedure. Meanwhile, the clinicians shame the narrator for her abortion, threatening her precisely with the loss of her reproductive capacities, and pathologising the form of her uterus: "[I]ls m'ont dit que si je ne faisais pas attention, après ces deux curetages je risquais de devenir stérile. Ils m'ont aussi dit qu'ils n'avaient jamais vu un utérus aussi bizarrement formé, [...] qu'il y a des tas

11 Indeed, the biopolitical insistence on reproduction in Truismes resonates with Lee Edelman's model of "reproductive futurism" in No Future, in which the imaginary figure of "the Child" serves to uphold mechanisms of socio-political control by "enacting a logic of repetition that fixes identity through identification with the future of the social order" (25). Edelman's equation of reproduction with repetition and political stasis echoes Malabou's critique of the reproductive logic inherent in flexibility (Que faire 167). 
de maladies qui traînent. Ils ont même gardé l'hystérographie pour l'étudier de près" (301 ; emphasis in the original). Reproduction is valorised whilst the plastic creation of the mutant uterus is rendered abject, and recorded by medical science as divergent and unacceptable precisely in its threat to reproductive, elastic repetition of the same. Just as the narrator deems her abortion necessary to not losing her job, Malabou also shows how the loss of flexibility equates to a loss of employability, comparing an unemployable worker to the pathological brain: "Nous savons très bien que toute perte de souplesse signifie la mise au rebut pure et simple. La différence est-elle vraiment si grande, qui sépare la représentation que nous avons d'un chômeur en fin de droits de celle que nous avons d'un malade d'Alzheimer ?" (Que faire 53).

Materialising a site of monstrous creation rather than elastic, pharmacopornographic reproduction, the narrator's mutant womb is a plastic form par excellence. In this way, the plastic womb challenges the figure of the obedient womb which has long haunted the theorisation of form in Western metaphysics, articulated famously as the khora of Plato's Timaeus (360BC) as the origin of form itself. In Bodies That Matter (2011), Judith Butler shows how Plato's concept of the khora, resembling the womb, condemns the feminine as a passive "receptacle" which can only receive forms without taking form itself; Plato's khôra-womb is elastic rather than plastic, a passive "receiving principle" which "has no proper shape and is not a body" (14). In her analysis of Luce Irigaray's own reading of the khora, Butler states: "the feminine is cast outside the form/matter and universal/particular binarisms. She will be neither the one nor the other, but the permanent and unchangeable condition of both - [...] a nonthematizable materiality" (16). The khora's immaterial, formless undecidability echoes "la défaite de l'identité" (Que faire 167) which Malabou sees in elasticity and flexibility.

Indeed, in Changer de différence (2009), following her own interrogation of the khôra, Malabou asks: "Comment sortir de l'itérabilité de la pensée du féminin comme entrave au concept, comment échapper à la fluidité ou à l'élasticité infinies de la matière femme ?" (148). For Butler, the khôra stop being a passive, excluded space for "phallomorphic genesis" (18), and itself be permitted to materialize "a future horizon, one in which the violence of exclusion is perpetually in the process of being overcome" (25). In other words, perhaps, the khorra must be rethought as plastic in Malabou's sense, in which the tripartite capacity to give, receive and explode form promises the possibility of creation beyond the form/matter binarism and opens form up to future (trans)formations ${ }^{12}$. Here, the khorra of the narrator's womb is divergent precisely because it dares to materialise, to take its own form alongside that which it forms, and become visible in the hysterography, protesting its metamorphic, plastic difference.

The expectation of the medical sciences in Truismes that the narrator's womb be a docile, reproductive receptacle echoes the description of the clones as "réceptacles d'organes" with empty brains in Notre vie. However, the narrator sees this emptiness not as a state of vacant elasticity, but indeed as the raw, plastic material for creating identity and history. Envisaging her clone as plastic rather than elastic, the narrator of Notre vie connects plasticity with the capacity for history, enabling the "future horizon" which Butler wants for the khôra. Talking about her clone, Marie, she states: "Je ne sais pas pourquoi, moi je la voyais comme l'avenir. Une page blanche à écrire. Toute cette disponibilité. Ce matériau brut, en quelque sorte. Beaucoup parmi nous ont eu le syndrome de Pygmalion, par la suite" (86). Imagining her clone as a narrative ready to be written, the narrator voices the possibility of removing the clone from the repeating technoscientific atemporality of "en sursis", rendering her clone capable of history geared towards an "avenir". Further, the

12 Indeed, Malabou's project in Changer de différence is to conceptualise the feminine "au-delà de l'essentialisme comme de l'anti-essentialisme" in terms of a plastic essence, "une essence vidée mais résistante, résistante parce que vidée, une frappe d'impossibilité" (115; emphasis in the original). 
possibility of writing a history for her clone imagines this narrative in sculptural, plastic terms, undermining the inscriptive logic of "[u]ne page blanche à écrire", with the "matériel brut" as well as her "syndrome de Pygmalion", which imagines her clone as the animate sculpture from Greek mythology, famously rendered in Ovid's Metamorphoses (8AD).

Whilst Malabou associates elasticity and flexibility with a vengeful atemporality which repeats precisely to occlude the possibility of the Event, as we have seen, plasticity is precisely the mode of being open to history and futurity by means of being open to difference and to the unexpected. The individual brain, for example, takes synaptic form in response to its precise history of experiences: 'L'œuvre propre du cerveau, qui engage l'aventure et l'histoire individuelles, porte un nom: la plasticité" (Que faire 40).

Further, plasticity's capacity for history is precisely what allows for autonomy and individuality: "Le fait que les synapses puissent voir leur efficacité renforcée ou affaiblie en fonction de l'expérience permet donc d'établir que, si tous les cerveaux humains se ressemblent quant à leur anatomie, aucun cerveau n'est identique quant à son histoire" (79). Even if the narrator's fantasy of the clone as a "page blanche à écrire" designates her as active writer and the clone as passive inscription, this hierarchy is undermined again by the reference to the story of Pygmalion in which the sculpture Galatea comes to life, taking on her own autonomy. Further, the clones' "souche" creators are later referred to as "les Frankenstein" (180) which again recounts a Pygmalion-esque tale in which the monstrous creation fails to comply with its creator, and escapes in search of freedom. Indeed, in Living Screens: Melodrama and Plasticity in Contemporary Film and Television (2015), Monique Rooney explicitly connects Jean-Jacques Rousseau's Pygmalion (1770) with Malabou's concept of plasticity; in the play, Rooney argues, Galatea's coming to life enacts the sculpture's "self-differentiation of the creation from its creator" (2), in which "Galatea ultimately withdraws from the artist who created her" in a way which "casts doubt on the idea that the created is assimilable to the desires and demands of the creator" (5). For Rooney, this withdrawal enacts the simultaneously constructive and destructive characteristics of Malabou's plasticity through which plastic form develops via a process of self-negation, becoming ever more differentiated from its source and thus inventing itself as a form of freedom (15-6). Just as the destructive-creative Galatea rebels against the one-sided constructive plasticity of her sculptor, the clones' own destructive-creative plasticity counters the elasticity of their technoscientific invention.

Indeed, despite their being genetically identical to their human originals, and their rescuers' attempts to teach and sculpt them in human ways, the clones misbehave, and resist the adoption of a perfectly human history. Describing the training of the clones as a process of anthropomorphic sculpturing, the narrator explains: "Le tout était de les muscler, de leur muscler la langue aussi et les mâchoires, de les entraîner en somme à la marche et à la parole $[\ldots]$ On creusait leur cambrure d'humain" $(13)^{13}$. However, the clones refuse their formation, in which "ces adultes soudain réveillés sont difficiles à discipliner. [...] les moitiés ne pensent qu'à s'amuser" (122). They are "à la fois soumis et insolent" (36), a duality which recalls the constructive-destructive character of Malabou's plasticity in which plastic form simultaneously takes form and resists transformation. Strikingly, the clones "se moquent de moi en m'imitant", resisting the human forms imposed upon them precisely in mockingly demonstrating their ability to imitate whilst refusing to take this imitation seriously. Further, they do not copy human behaviour to the letter, walking like penguins (36). At times, the scene is one of anarchy:

13 Note here the presence of the phrase "cambrure d'humain", also employed at the end of Truismes when the narrator declares: "moi c'est pour retrouver ma cambrure d'humain que je tends mon cou vers la Lune" (158). The "cambrure d'humain", it seems, is not something that happens naturally but something that is sculpted: the human is but one of infinite plastic possibilities for a body. 
Libérer les moitiés nous mettait tous d'accord; c'était leur usage, qui nous divisait. [...] On se battait et on buvait. Les moitiés s'accroupissaient en cercle autour de nous et nous chipaient de la gnôle et des morceaux de rats. Elles rigolaient. Elles nous regardaient nous battre. Ensuite, à la lueur des dernières flammes, elles copulaient. On n'arrivait pas à stériliser tout le monde, trop de moitiés et pas assez de matériel. On avait des problèmes de bébés. (158)

Whilst the reproductive politics of Truismes and the commercial production of clones in Notre vie connote the maintenance of the enslaved khora by the controlling sciences, here reproduction is rendered carnivalesque: rabid and excessively overproductive. This excessiveness characterises the clones' plasticity: a plasticity that engages with the humans, is moulded by them, but also refuses to repeat this humanity perfectly, even throws it back at the humans mockingly. Plastic reproduction, liberated from the vengeful atemporality of elastic science, refuses to behave and repeat. In this way, the clones, originally products of an unconscious and repeating science, fulfil Malabou's challenge to "repeat plastically", mobilising "the possibility of sculpting the human to come, that creator of new genealogies, deprived of originary guilt, ready to play anew" ("Repetition, Revenge, Plasticity" n. pag.).

The clones' plasticity allows them to resist appropriation by their liberators, who argue about what to do with them. Further, the clones' nonhumanness is a constant source of frustration for the humans: “Certes, elles n'ont pas de passé. C'est difficile à penser. Certains d'entre nous réclament un effort d'empathie, pour nos moitiés. 'Elles sont comme nous' ils disent. Mais ce discours a du mal à passer. Le 'comme-nous', on en a soupé" (126). Here, the discord comes from the fact that the clones are different precisely because they have a different relation to time and to history; whilst the clones, now plastic following their liberation from their elastic slumber, are capable of history, it is a different mode of history to that of their liberators: this is a history built not on the pretence of past or origin, but articulated as a temporal openness in which there is nothing but future.

In repeating differently and plastically the humanity that their liberators try to teach them, the clones plasticize and mutate the very notions of difference and history themselves. In Que faire, Malabou argues that we should see cerebral plasticity not just as a capacity for neural history in the linear or teleological sense, but as the possibility of creating new forms of history itself, in which we strive to "savoir ce que le cerveau peut faire et pas seulement tolérer". Here, "faire" means "pas seulement 'faire' des mathématiques ou du piano, mais faire son histoire, devenir le sujet de son histoire, saisir le lien entre la part de non-déterminisme génétique à l'œuvre dans la constitution du cerveau et la possibilité d'un non-déterminisme social et politique, en un mot d'une nouvelle liberté, d'une nouvelle signification de l'histoire" (58; emphasis in the original). In reclaiming their plasticity following their artificially induced hibernation, the clones' resistance does not simply consist in injecting history and temporality back into the scientifically-maintained atemporality of Notre vie's immortal populations, but in sculpting new forms of historical temporality that, anchored to no fixed past or origin, are entirely open to the future and to the unexpected, and therefore to freedom. Indeed, from L'Avenir de Hegel (1996) onwards, the question of plasticity for Malabou has been inextricably linked to the question of time, and in particular the capacity to theorise history not as a simple progression of events or a retrograde looking-back, but indeed as exposed to unforeseen futures and to the Event ${ }^{14}$. Her assertion in Que faire that "les synapses sont les réserves d'avenir du cerveau" (80), therefore, implants the plastic futurity that she

14 As Ian James sums up, Malabou's L'Avenir de Hegel articulates the Hegelian subject's plastic (trans)formation through time as an anticipatory "voir venir" which implies "not anticipation in the mode of mastery or appropriation of the event, but rather a mode of exposure to it, to its ungraspable alterity, and therefore a vulnerability to being deformed, reformed or transformed by it" (The New French Philosophy 88). 
discovers in Hegel as a potentiality at work in cerebral materiality itself. Without past, the clones replace the "revengeful" eternal return of atemporality reproduced by the technosciences with a plastic history exposed to and sculpted uniquely by the future, and therefore by freedom.

This transformation of history itself is echoed in the narrator's own telling of her story, which fails to locate its narrative in relation to any fixed origin, and instead generates plural, non-linear, and open-ended histoires. This testimony invents its own forms of history against technoscientic atemporality and organising future resistance against it. She warns: "Ne comptez pas sur moi pour organiser tout ça. J'essaie de suivre un fil chronologique mais ça rate" (26). She insists repeatedly on the need to testify - "il faut que je raconte cette histoire" (9) - whilst also pointing to the plurality of this testimony, which works by "rameutant les morceaux" (9), and which is being carried out by several of the other runaways: "Nous sommes plusieurs à écrire" (41). The testimony also contains a lot of repetition; for example, the narrator tells of the first time she met her clone time and time again, saying "La première fois s'est additionnée aux autres fois. Mêlée. Tant pis pour la chronologie" (78), yet each retelling is different, again mobilising Malabou's insistence in "Repetition, Revenge, Plasticity" that plasticity is repetition with difference. The verb "rameutant" does not necessarily connote a gathering up or unification of fragments, but indeed a mobilisation of these fragments, activating the plastic testimony without reducing its plurality or mutability. In this way, the narrator's testimony is mobilised as a truly plastic, unanchored discourse which, with its very form, resists and fights against the totalising elasticity and atemporality of the technoscientific universe from which they have escaped. This testimony plans to install a history precisely as an openness to futurity within the scientifically reproduced atemporality. The narrator compares her cahier to the works of the Lascaux caves, preserving different forms of narrative for future generations (16), locating her resistance to the totalitarian regime precisely in securing a future rather than locating a past. Further, when the narrator realises that she too is one of a lineage of clones - a copy of a copy of a copy - her narrative is revealed not to have been building to the revelation of an origin, but precisely to the absence of origin, revealing the origin itself as a plural, plastic form that avoids capture.

This mobilisation of testimony as itself a plastic textual form which is open to transformation and futurity, resisting the atemporality and political vacancy of Notre vie's totalitarian sciences, is also present in the narrator's testimony in Truismes. The novel opens with a flash-forward in which the narrator, now a sow, describes the physical difficulty of the act of writing following her transformation. This difficulty is presented in terms of both physical and mental limitations, and itself stages a movement from writing as a fluid, dynamic act to writing as a laboured work of plastic sculpturing:

Or tenir un stylo me donne de terribles crampes. Je manque aussi de lumière, je suis obligée de m'arrêter quand la nuit tombe, et j'écris très, très lentement. Je ne vous parle pas de la difficulté pour trouver ce cahier, ni de la boue, qui salit tout, qui dilue l'encre à peine sèche. J'espère que l'éditeur qui aura la patience de déchiffrer cette écriture de cochon voudra bien prendre en considération les efforts terribles que je fais pour écrire le plus lisiblement possible. L'action même de me souvenir m'est très difficile. Mais si je me concentre très fort et que j'essaie de remonter aussi loin que je peux, c'est-à-dire juste avant les événements, je parviens à retrouver des images. (9-10)

Just as the clone in Notre vie is imagined as a "page blanche" which is sculpted rather than inscribed, here, writing is a form of sculptural work that now exceeds the logic of inscription. Indeed, whilst the scientific hysterography polices the narrator's body via the inscriptive logic of the x-ray image which renders static the narrator's mutant body in order to label and pathologise it, controlling though ossifying, the narrator's own writing 
demonstrates an embodied, sculptural work which resists and exceeds normative legibility. The physical body of the sow is unsuited to holding a pen, her new environment away from the electric lights makes it hard to see what she is writing, and traditional writing materials are almost impossible to find. Ink is here contrasted with mud; the thicker, unruly, malleable substance of the mud interrupts the fluidity of the ink, pushing against and interrupting writing, and forging the "écriture de cochon" through a constructivedestructive process. In this way, mud becomes a narrative plastic materiality which sculpts testimony through a giving, receiving and resisting of textual form. The mutant narrator's insistence upon the difficulty of remembering the tale, and the psychic effort involved in the act of remembering, casts the act of writing not as a simple inscription of concrete and teleological remembered past events, but the active plastic creation of new forms and narrative assemblages. The narrator's laboured concentration evokes "images" rather than chronologies, demonstrating new forms of narrative to be created alongside the new sculptural forms of text. Countering Naama Harel's argument that Truismes enacts a "psycho-physical split" in which the narrator's internal psyche is severed from the mutation of her body (399), the reading of the narrator's text as plastic shows how psychic, corporeal, and textual form and content transform plastically in symbiosis, articulating forms of freedoms precisely as a new form of histoire ${ }^{15}$. Beginning here, Truismes presents us with an author who is mid-transformation and with a plastic text that is itself always already mutant. We never find out why or how the narrator is transforming; the narrator's plastic histoire is not concerned with a history of origin, but is first and foremost the exploration of the potentialities of the plastic body which, liberated from the technoscientific injunction to be flexible, opens itself up to unforeseen future transformations ${ }^{16}$.

In La Plasticité au soir de l'écriture (2005), Malabou argues that the logic of writing is being superseded by the logic of plasticity. Here, she charts the passage from the graphic era - an era characterised by writing, by the trace, by the logic of inscription - into a plastic era. This plastic era is inspired by scientific discoveries which demonstrate that organisms are no longer determined by the inscription of their genes but open to contingency and to the capacity to self-sculpt, such as the neuroplasticity of the brain or the body's modifiability beyond its genes in epigenetics. For Malabou, plasticity emerges in the residual forms left behind following a text's own deconstruction: "La lecture plastique d'un texte est celle qui entreprend de mettre au jour la forme laissée en lui par le retrait de la présence, c'est-à-dire par sa propre déconstruction" (99; emphasis in the original). Turning to molecular biology, for instance, Malabou argues: "la plasticité prend forme là où l'ADN n'écrit plus" (112; emphasis in the original). Plasticity takes over from writing once the gene has been rescued from the genetics of scientific determinism, and the organism has been rescued from the inscription of its DNA. In elaborating a plasticity after writing, then, Malabou suggests how scientific discoveries of organic plasticity exceed and interrupt ideological inscriptions of control at the heart of science. In this way, Malabou activates science as a plastic text of its own deconstruction.

Indeed, in Notre vie, the narrator explicitly connects the act of writing to plastic changes in her brain which undo and de-toxify the repeated labour patterns of the technoscientific totalitarian regime.

15 Kemp's own reading of Truismes also seeks to deconstruct Harel's "psycho-physical split", arguing that the protagonist's transformation is as psychological as it is corporeal (Writing the Mind 165).

16 In an interview, Darrieussecq says: "I don't know what causes my character's transformation [...] a nuclear disaster as a clin d'œil to the science fiction novels I read when I was a teenager; or the mere way men look at her as a unique case of suggestion [...] Or maybe it was caused by an eating disorder pushed to a limit; or anger; or desire [...]. But none of these reasons is the reason: it just HAPPENS", quoted by Damlé in The Becoming of the Body (130-31). 
Écrire ici sur un cahier, et avec une seule main (la droite, chez moi), a sûrement défait dans mon cerveau des habitudes liées à l'usage à deux mains du clavier, puis à l'usage de mes deux mains comme souris. Cesser de produire dans l'espace, tels des moulins à vent, ces gestes sans cesse répétés de mise en route et guidage de nos appareils, de nos casques, de nos véhicules pour ceux qui en ont, de nos chiens, etc., est une désintoxication radicale de notre monde, ni plus ni moins. On sort du monde. On se retrouve dans la forêt. (120)

The brain's plasticity, here, creates, heals, and resists the act of writing; the technological, inscriptive repetition of typing shifts to the narrator's current text as the source of plastic transformations in the brain that organically deconstruct these repetitions, leaving behind a form of testimony in the wake of this deconstruction. Meanwhile, in Truismes, the more plastic the narrator's body and text become, the more the narrator directly refers to the neural materiality of her brain as a locus of mutability and transformed consciousness, rendering as literal, cerebral anatomy Malabou's claim that plasticity is the "conscience à venir de la flexibilité" (Que faire 56; emphasis in the original). Further, the narrator's conception of her own brain changes from a medicalised understanding of neuropathology at the beginning, to an anarchic source of pluralised identities and forms of being, and even a site of ecological communion and communication with the forest of her exile. Early in her transformation, the narrator becomes convinced that her transformation has a neurological cause, imagining the brain as the cause of interconnected mutations across her body: "J'étais de plus en plus persuadée que j'avais quelque chose au cerveau, une tumeur, je ne sais pas, quelque chose qui m'aurait à la fois paralysé l'arrièretrain, troublé la vue, et un peu dérangé le système digestif' (75). Beyond this medicalized understanding of the brain as a site of pathology to be policed and corrected, however, the brain of the increasingly exiled, mutant narrator is evoked as a site of creative, organic life unchecked by scientific limits.

This unchecked brain emerges at moments when the narrator switches between the various states of consciousness which become more volatile and multiple as the metamorphosis continues. In one sequence, for example, fleeing from some piranhas, the narrator suddenly realises what is happening and states " $[\mathrm{m}]$ es neurones se sont remis en place" (97). These later imaginings of the brain make no localised, inscriptive "diagnosis", like the hysterography does with the uterus, but imagine the brain as a plastically creative, organic materiality emancipated from scientific and medical control. Here, the plastic brain and its neurons migrate and self-activate anarchically in defiance of any diagnostic territorialisation. The plural "neurones" acts to multiply and disperse the singular "cerveau", again pluralising the plastic forms of identity and histoire simultaneously at play in the narrator's testimony as in Notre vie. For Malabou, whilst neuroscience has provided a detailed picture of the functioning of the brain, it has not yet succeeded in engendering a "conscience du cerveau" (Que faire 36-8); rather, "[i]l ne s'agit donc pas seulement ici de révéler, sous le nom de plasticité cérébrale, une certaine liberté du cerveau, mais encore, à partir d'une étude aussi précise que possible du fonctionnement de cette plasticité, de libérer cette liberté. De la dégager d'un certain nombre de présupposés idéologiques qui gouvernent implicitement tout le champ neuroscientifique et, par effet de miroir, tout le champ politique" (54). In freeing the brain in Truismes from any ideological use of science to appropriate or diagnose the brain as a finite cartography of human structures or pathologies, the plastic brain is liberated to invent new forms of future consciousness which extend beyond the pathological/healthy binary, beyond the singular body, and beyond the human.

Indeed, Watkin suggests that Malabou's thinking of (neuro)plasticity invites an ecological thinking of the new plastic self which "moves beyond the subject/object dichotomy and opens onto an ecological understanding of identity" (140). This eco-plastic 
dispersal of the distinction between subject and object reverses the strict power hierarchy characterised by the perfume shop and the clinic which enslave the narrator in the first part of the novel and attempt to reduce her to a singular, compliant object of technoscentific control. In the forest, rather, the eco-plastic narrator describes the non-human landscape of relations and sensations with which she is now in communication:

Dans tout mon corps j'ai viré à nouveau avec le tournoiement de la planète, j'ai respiré avec le croisement des vents, mon cœur a battu avec la masse des marées contre les rivages, et mon sang a coulé avec le poids des neiges. La connaissance des arbres, des parfums, des humus, des mousses et des fougères, a fait jouer mes muscles. Dans mes artères j'ai senti battre l'appel des autres animaux, l'affrontement et l'accouplement, le parfum désirable de ma race en rut. L'envie de la vie faisant des vagues sous ma peau, ça me venait de partout, comme des galops de sangliers dans mon cerveau, des éclats de foudre dans mes muscles, ça me venait du fond du vent, du plus ancien des races continuées. (149-150)

If, as Simon Kemp argues, Darrieussecq's focus on the materiality of the brain allows her to imagine states of consciousness which exceed and deform language (French Fiction 94), in the above passage neural life seems to exceed the brain as static, singular organ, articulating this neural life as a plastic ecology ${ }^{17}$. This plastic, ecological life is not confined to the "inner world" of the mind, but rather opens up a transforming ecology of extensions and reverberations; the "galops de sangliers" in the narrator's brain communicate and mutate in contact with other organs, animals, plants, and surfaces, be this an understanding of the trees or a scent-sense of fellow pigs' mating rituals. Rather than Kafka's claustrophobic imagining of metamorphosis in The Metamorphosis (1915) in which Gregor Samsa is locked inside the body of a beetle, psychic content separated from bodily form (Harel 399; Malabou, Ontologie de l'accident 23), Truismes' narrator is beside herself, extending into and within the rhythms of her plastic environment. Meanwhile, the pig's movements around her mud pit describe a giving and taking of form in which she plastically manipulates and fertilises her environment: "J'ai creusé des quatre pattes, j'ai fait caca, je me suis roulée, ça a fait un beau trou oblong plein de vers réveillés et de vesses de loup en germe" (149). The narrator now inhabits new modes of dwelling and communion which are co-invented between plastic self and plastic world. The "ecological subjectivity" that Stephanie Posthumus identifies in Darrieussecq's work (26-59) here becomes an ecological plasticity in which a landscape invents and creates new forms of life precisely in the de(con)struction of the singular, elastic body maintained and reproduced through the prior technoscientific landscape.

Truismes and Notre vie, then, both see organic plasticity - of the pig, of the clone, of ecology - as a mutant and transformative mode of resistance which escapes a totalitarian science's regimes of control by countering this science's logics of elastic repetition, sameness, and atemporality with a plasticity that prizes new forms of history characterised by an openness to plurality, to difference, to the unexpected, and to futurity. Both novels end in the forest, a space which at first glance might appear opposite to technological artifice and totalitarian control. However, in this final section I consider how the forest does not necessarily entail a simple hideaway from science's control, but instead emerges as a fertile space to experiment with the possibility for the becoming plastic of science itself, saving science from its own ideological capture.

17 Indeed, while Kemp demonstrates the centrality and the complexity of the physical brain in Darrieussecq's work, he does not explicitly explore the brain's neuroplasticity, and mentions the brain in Truismes only briefly (French Fiction 81-2; Writing the Mind 165-66). In my own reading, I suggest that descriptions of the brain in Truismes necessarily connect neural materiality with the question of metamorphosis and the plasticity of organic form, rendering Truismes perhaps Darrieussecq's most neural text in its exploration of brain-body plasticity. 
Benjamin Dalton

\section{Towards a Plastic Science}

Both Notre vie and Truismes, then, document a passage from the controlling capitalist sciences of futuristic, urban totalitarian states into the seemingly "natural" setting of nature in the forest. However, whilst Truismes' narrator seems to have completely escaped all traces of technoscientific civilisation, the narrator of Notre vie is only too aware of how the forest provides no simple escape from the science that she is running from. The narrator talks about how small the world is, how "on n'a plus tellement où se cacher nulle part sur la Terre" (14-5), and how even the forest will have soon disappeared (18). Problematically, the narrator also still has a microchip in her brain, maintaining the connection with the technoscientic system of control she is escaping; this microchip cannot be taken out with the basic surgical tools available in the forest (118), and the narrator worries that she can be controlled from a distance (119). Further, the universe of Notre vie is populated by a plurality of robotic and genetically engineered human and animal life which disallows any clear distinction between organic and scientifically manipulated life, a realisation that becomes all the more pertinent after the narrator's revelation that she too is a genetically engineered clone. The forest as a space of pre-scientific nature, the narrator shows, is a nostalgic construction. The narrator fashions the forest as a psychic "lieu sûr" (50) in which she imagines walks "dans la forêt d'il y a longtemps" (105). Here, in the forest where the distinction between organic and technoscientific becomes moot, Darrieussecq's thinking of plasticity in Notre vie parts ways with that of Truismes; now, Darrieussecq must think a plasticity of resistance from within technoscientific creation rather than as its outside.

Indeed, the overly hasty differentiation between technological and organic life is one which Malabou addresses in Métamorphoses de l'intelligence (2017), confessing with reference to Que faire: "La différence entre plasticité biologique et flexibilité technologique que j'avais inscrite au cœur de mon livre n'en était donc pas une" (119). In light of advances in artificial intelligence in which the robotic imitation and simulation of organic neural synpases is being foreseen (108), Malabou admits that it is a fallacy to imagine the technological apart from the biological, and to imagine a form of resistance outside of the ever-collapsing proximity between human and machine. Malabou turns to the double meaning of the word "automatisme", which evokes simultaneously something animated by a force outside of itself and something which is animated precisely by itself, moved by itself, autonomous (127). Intelligence, whether "artificial" or "organic", is that which "oppose le pouvoir de l'automatisme aux automatismes du pouvoir, et fait jouer un sens de l'automatisme contre l'autre" (127). Agency and freedom can no longer be thought of as separable from the machinic, and technology needs no longer be seen as the enemy of plasticity or of freedom.

Locating our future plastic resistance to the flexible technosciences of control precisely in our relationship with machines rather than in our opposition of them, Malabou suggests that machines might in fact extend our plasticity, invent the plasticity of the future, and provide potent plastic tools for social transformation and revolution. Now, we can

concevoir une interaction entre cerveaux et machines qui reposerait sur leur capacité réciproque à provoquer, les uns chez les autres, des ruptures, des échecs ou des catastrophes et les mettrait ainsi mutuellement au défi d'atteindre de nouveaux seuils de régulation, de se transformer et se réorganiser en réponse à ces défis, rendant toujours plus improbable la différence entre mécanisme et autonomie. (Métamorphoses 152)

It is only through the social interaction between the biological and the technological that a true future politics of plasticity can be invented. Further, it is only in the intermingling of technological and organic plasticity that we might be able to imagine and invent future communities composed of a diversity of non-totalising plastic intelligences: 
"L'épanouissement d'une telle pluralité d'intelligences 'naturelles' n'est évidemment pas possible sans le secours de la plasticité de l'intelligence technique" (158).

When the narrator's resistance group emancipates the clones and absconds with them into the forest, this newly formed community - of clones, animals, brains with technological implants - imagines Malabou's "pluralité d'intelligences" in which technology and biology mutually organise, program, and assemble a constructivedestructive plasticity "des ruptures, des échecs ou des catastrophes", of "de nouveaux seuils de régulation", and of transformation as a site of plastic resistance and creativity, and as the sculpting of a revolutionary community to come.

Indeed, the presence of the microchip in the narrator's brain asks precisely this question: how is it possible for the narrator to escape the technological servitude of the world surrounding her when the kernel of this fascist science is irrevocably embedded in her brain, inseparable from it and indeed the condition of its functioning? This question, it seems, is the very question tackled here in the encounter between Darrieussecq's and Malabou's plasticities at the edge of science: does the plasticity of the embodied subject herald an infinite mutability and creativity that will always evade scientific and technological attempts at capture and mastery under neoliberal advanced capitalism, or does a true plasticity of freedom appear precisely at the site at which the biological and the technological are most intimately connected? The narrator claims that she has found a way to disrupt the cerebral microchip in the same way that one might disrupt an external device, promoting breakages and vacillations in its connections: "Mais on peut se déconnecter de l'intérieur aussi. Il faut trouver sa chambre intérieure. Ne penser à rien, rien, pendant quelques minutes, fait déjà vaciller la connexion. [...] Dézoner le cerveau. Et repérer en soi la source du réseau" (118; emphasis in the original). At the end of the novel, the narrator feels changes occurring in her brain that she cannot attribute either to the microchip or to her brain: "Ça me fait des chocs. Ça se dérègle, peut-être. Ça m'envoie des trucs que je ne maîtrise plus. [...] Mais c'est peut-être mon propre cerveau, dont les tissus se nécrosent au contact du module. Et pas du tout le module qui se corrode, comme je l'avais espéré. Ou peut-être que sa corrosion attaque mon cerveau" (185). Neither fully brain nor machine, the narrator's transformable plasticity constitutes a giving, receiving and destruction of form which occurs precisely because of the intimate proximity between the two, between the technoscientific and the organic.

Plasticity, as we have seen, names the site of potent mutability at which foreign discourses transform, create, and take form together when they come into contact, be this science, technology, and organic life, science and philosophy, science and literature, literature and philosophy, or Darrieussecq and Malabou. As James argues, plasticity evidences an "ontological groundlessness" ("(Neuro)plasticity, Epigenesis and the Void" 1), which catalyses "the speculative moment that arises and necessarily imposes itself when both philosophy and science come to the limit of what they can currently or constitutively determine of being" (18). The destructive-creative force of these encounters, truly plastic, presents us with changes in transformation and new forms of freedom precisely at the site at which plasticity becomes a science and in return teaches science to become plastic. How not to hear a philosophy of plasticity in the words of the mutant narrator of Truismes who voices the teachings of her transformation as a consciousness of the plastic destructivecreations of the world around her: "Je sais aujourd'hui que la nature est pleine de contraires, que tout s'accouple sans cesse dans le monde, enfin, je vous fais grâce de ma petite philosophie" (55). 


\section{WORKS CITED}

Asibong, Andrew. "Mulier Sacra: Marie Chauvet, Marie Darrieussecq and the Sexual Metamorphoses of 'Bare Life"”. French Cultural Studies 14.2 (2003): 169-77. Print.

Brilmyer, S. Pearl. "Plasticity, Form, and the Matter of Character in Middlemarch". Representations 130.1 (2015): 60-83. Print.

Butler, Judith. Gender Trouble: Feminism and the Subversion of Identity. London: Routledge, 1999. Print.

---. Bodies that Matter: On the Discursive Limits of "Sex". London: Routledge, 2004. Print.

Damlé, Amaleena. "Posthuman Encounters: Technology, Embodiment and Gender in Recent Feminist Thought and in the Work of Marie Darrieussecq". Comparative Critical Studies 9.3 (2012): 303-18. Print.

---. "The Flux and Folds of Consciousness: Marie Darrieussecq's Literature of Simulation and Dispersal". The Becoming of the Body: Contemporary Women's Writing in French. Edinburgh: Edinburgh U P, 2014. 123-53. Print.

Darrieussecq, Marie. Truismes. Paris: P.O.L, 1996. Print.

---. Notre vie dans les forêts. Paris: P.O.L, 2017. Print.

Darrieussecq, Marie, and Jeannette Gaudet. “ 'Des livres sur la liberté' : conversation avec Marie Darrieussecq”. Dalhousie French Studies 59 (2002): 108-18. Print.

Edelman, Lee. No Future: Queer Theory and the Death Drive. Durham: Duke U P, 2004. Print.

Foucault, Michel. The History of Sexuality 1. The Will to Knowledge. Trans. Robert Hurley. Harmondsworth: Penguin Books, 1998. Print.

Gaudet, Jeanette. "Dishing the Dirt: Metamorphosis in Marie Darrieussecq's Truismes". Women in French Studies 9 (2001): 181-92. Print.

Haraway, Donna J.Modest_Witness@Second_Millennium.FemaleMan ${ }^{\odot}$ _Meets_OncoMo use ${ }^{\mathrm{TM}}$ : Feminism and Technoscience. New York: Routledge, 1997. Print.

Harel, Naama. "Challenging the Species Barrier in Metamorphosis Literature: The Case of Marie Darrieussecq's Pig Tales". Comparative Critical Studies 2.3 (2005): 397-409. Print.

Hubard, Gabriela García. "Quelques réflexions : de la plasticité aux discours postcoloniaux". Expressions maghrébines 14.1 (2015): 155-72. Print.

James, Ian. The New French Philosophy. Cambridge: Polity, 2012. Print.

---. "(Neuro)plasticity, Epigenesis and the Void". Parrhesia 25 (2016): 1-19. Print.

Kafka, Franz. "Metamorphosis". Metamorphosis and Other Stories. Trans. Michael Hoffman. London: Penguin Classics, [1915] 2015. 85-146. Print.

Kemp, Simon. "Marie Darrieussecq and the Voice of the Mind". French Fiction into the Twenty-First Century: The Return to the Story. Cardiff: U of Wales P, 2010. 76-95. Print.

---. "Brain: Marie Darrieussecq". Writing the Mind: Representing Consciousness from Proust to the Present. New York: Routledge, 2017. 149-77. Print.

Malabou, Catherine. L'Avenir de Hegel: plasticité, temporalité, dialectique. Paris: J. Vrin, 1996. Print.

---. La Plasticité au soir de l'écriture : dialectique, destruction, déconstruction. Paris : Léo Scheer, 2005. Print.

---. Ontologie de l'accident : Essai sur la plasticité destructrice. Paris: Léo Scheer, 2009. Print.

---. Changer de différence. Le Féminin et la question philosophique. Paris : Galilée, 2009. Print.

---. "The Future of the Humanities". theory@buffalo 14 (2010): 8-16. Print.

---. Que faire de notre cerveau? Paris : Bayard, [2004] 2011. Print.

---. “What is Neuro-literature?". SubStance 45.2 (2016): 78-87. Print. 
---. Les Nouveaux Blessés : de Freud à la neurologie, penser les traumatismes contemporains. Paris : PUF, [2007] 2017. Print.

---. Métamorphoses de l'intelligence : que faire de leur cerveau bleu ? Paris: PUF, 2017. Print.

---. "Repetition, Revenge, Plasticity". E-Flux. 21 February 2018.

$<$ www.e-flux.com/architecture/superhumanity/179166/repetition-revenge plasticity/>. (Accessed 19 March 2018). Web.

Malabou, Catherine, and Jean-Marie Durand. "Pour la rencontre entre philosophie et neurosciences". Les Inrockuptibles. 20 October 2014.

$<$ https://www.lesinrocks.com/2014/10/20/livres/catherine-malabou-rencontrephilosophie-neuro-sciences-11530745/>. (Accessed 13 June 2018). Web.

Moder, Gregor. "Catherine Malabou's Hegel: One or Several Plasticities?" Filozofija I Duštvo 26.4 (2015): 813-29. Print.

Ovid. Metamorphoses. Trans. by David Raeburn. London: Penguin Classics, 2014. Print.

Phillips, Thomas. Liminal Fictions in Postmodern Culture: The Politics of SelfDevelopment. New York: Palgrave Macmillan, 2015. Print.

Pickering, Andrew. The Mangle of Practice: Time, Agency, and Science. Chicago: U of Chicago P, 1995. Print.

Plato. "Timaeus". Timaeus and Critias. Trans. Robin Waterfield. Oxford: Oxford U P, [360 BC] 2008. 1-99. Print.

Posthumus, Stephanie. "Ecological Subjectivity: Guattari and Darrieussecq". French Écocritique: Reading Contemporary French Theory and Fiction Ecologically. Buffalo: U of Toronto P, 2017. 26-59. Print.

Preciado, Paul B. Testo Junkie: Sex, Drugs, and Biopolitics in the Pharmacopornographic Era. New York: The Feminist Press at the City University of New York, 2013. Print.

Rooney, Monique. Living Screens: Melodrama and Plasticity and Contemporary Film and Television. London: Rowan \& Littlefield, 2015. Print.

Rousseau, Jean-Jacques. "Pygmalion". Pygmalion de Rousseau, scène lyrique, suivi de Arlequin Marchand de poupées ou Le Pygmalion moderne de Charles-Jacob Guillemain. Saint-Gély-Du-Fesc: Ed. Pauline Beaucé, 2012. Espaces 34. 19-28. Print.

Trout, Colette. Marie Darrieussecq ou voir le monde à neuf. Amsterdam: Rodopi/Brill, 2016. Print.

Tyrer, Ben. "Trauma Without a Subject: On Malabou, Psychoanalysis and Amour". Psychoanalysis and the Unrepresentable: From Culture to the Clinic. Ed. Agnieszka Piotrowska and Ben Tyrer. London: Routledge, 2016. 20-38. Print.

Watkin, Christopher. French Philosophy Today: New Figures of the Human in Badiou, Meillassoux, Malabou, Serres and Latour. Edinburgh: Edinburgh U P, 2017. Print.

Williams, Tyler. "Plasticity, in Retrospect: Changing the Future of the Humanities". Diacritics 41.1 (2013): 6-25. Print. 